\title{
Nutraceutical values of fish demand their ecological genetic studies: a short review
}

Biswaranjan Paital[1]

\begin{abstract}
Background: Fish act as an affordable source of animal protein as well as the source for many other substances of nutraceutical importance. Under rapid biomagnification of pollutants, low tolerance to climatic stressors increase susceptibility of various fish to large-scale mortality. Therefore, understanding the magnitude and type of their responses to individual or multiple climatic factors/stressors may help to conserve the genome of threatened organisms of pharmaceutical or nutraceutical importances such as fish. The study of the broad range of genetic material under varied climatic conditions, i.e., ecogenomics, such as nucleotide sequences of DNA and RNA that is present in the same fish species under particular environmental condition due to climatic changes seems to be important for their management.

Aim: The aim of this study was to gather information about nutraceutical values, ecogenomics data, and issues related to handling ecogenomics data and to identify limitations to study influences of climatic changes that may lead to design appropriate conservation strategies, despite existence of multiple constraints for conservation implications against climate change adaptations.

Method: Related literature in PubMed and other electronic database were analyzed for this study. As per the requirement, the numbers of articles found on a particular terminology such as "fish," "ecogenomics," and "ecogenomics in fish," in PubMed were only included.

Results: It was observed that despite high nutritional and nutraceutical values of fish, study on their ecogenomics is very limited. Rate of climate change, restraints to climate change adaptation, several limitations to migration, constraints to in situ adaptation, connectedness of populations and level of gene flow, and capacity of plasticity for adaptation are many of the constraints that lead to changes in fish physiology, but the effects of such constraints on genomic instability in fish are scantily studied. On the other hand, a huge amount of generated ecogenomic data on other organisms create challenges for annotation of protein and gene sequences. However, the challenges are now gradually becoming achievable to counter the ecogenomic issues.
\end{abstract}

Conclusion: Emphasis must be given to study on ecogenomics changes in fish and other aquatic organisms. Conserving germplasm of endangered and threatened fish species, and delivering genetically resistant fish variety, seem to be essential for effective management actions under climatic altered states. It will assist adaptation of fish having nutraceutical values in the face of current and future climate changes and chemical pollution in environments particularly in aquatic ecosystems.

Keywords: Biotechnology approaches, Bioinformatics approaches, Climate change, Ecogenomics, High-speed urbanization, Large-scale die-off events, Fish, Nutraceuticals 


\section{Background}

A fish is a paraphyletic group of organisms that consist of all gill-bearing aquatic craniate animals that lack limbs with digits (Paital \& Rivera-Ingraham, 2016). Fish being poikilotherm is a natural and prime target to subtle increase in temperature of their habitat as a consequence of global warming (Paital \& Chainy, 2016). This is because these organisms along with some of the homeotherms as well, lack proper physiological mechanism(s) to regulate internal body heat in relation to changing environmental temperature (Carey \& Lawson, 1973; Goldman, 1997; Lefevre, McKenzie, \& Nilsson, 2017; Markovic et al., 2017; Paital et al., 2014, b; Paital et al., 2015; Paital et al., 2016; Paital \& Tripathy, 2015). Other climatic and chemical stressors are also believed to discharge similar pressure on different organisms including fish, albeit the titer of the stressors controls (Chainy et al., 2016; Paital \& Bohidar, 2011; Paital, 2016d; Paital \& Chainy, 2014. Samanta \& Paital, 2016; Subudhi et al., 2008, 2009) specific molecular uphill or down regulation, and finally, it leads to inconsistent cellular physiology (Paital \& Chainy, 2013a; Paital, 2014b). Consequently, their energy metabolism may be susceptible under changing environmental temperature and air exposure like stressors (Galli \& Richards, 2012; Millan et al., 2017; Paital, 2013; Paital, 2014b; Paital \& Chainy, 2014). Increase in metabolism due to elevated environmental temperature may be reflected by some unwarranted biochemical reactions. As a result, it may cause development of oxidative stress in the species leading to various pathophysiological changes which may span from retarded growth, faulty reproduction to early aging, and finally death (Chainy et al., 2016; Millan et al., 2017; Paital, 2016b; Paital, 2017; Paital et al., 2016, b; Paital et al., 2017; Anonymous, 2017).

In poikilothermic animals such as fish, cellular metabolic depression or shut down induced by climatic stressors is expected to stimulate multiple changes at genomics level (Chainy et al., 2016; Paital \& Rivera-Ingraham, 2016; Paital, Bal, Rivera-Ingraham, \& Lignot, 2017). Unfortunately, a focused review article indicating ecogenomic studies and related issues is not available in the literature. Various organisms susceptible for climatic factors such as fish are to be studied at their genomics instability level. Therefore, it is an appropriate time to have scientific studies that are necessary to unveil the interaction between the changing global warming and genome of poikilotherms in general and fish in particular.

Ecogenomics study included the accumulation of slow changes in genome of organisms under environmental pressures. Under such long-term condition, the same species in different localities of globe slightly differs at their genome level. These are detected using molecular taxonomic tools at nucleotide level, even at single nucleotide polymorphism level. Present-day climate change issues have widespread effects on organisms (Rocha et al., 2017; Wu et al., 2017). Climatic factors may also influence genomics of various organisms including that of aquatic one. It is because of rapid biomagnification of pollutants and other anthropogenic factors probably that create accumulation of mutation albeit that takes millions of years (Ali et al., 2017; Buczkowski \& Bertelsmeier, 2017; Hermoso, 2017). Literature suggests that works on climate change induced ecogenomics changes in animals in general and aquatic animals in particular have received least attention. Aquatic animals are more susceptible to several man-made and natural insults, as results of accumulation and biomagnification of pollutants as well as due to their poikilothermic nature (Paital, 2013; Paital, 2014a, 2014b; Paital \& Chainy, 2016; Paital et al., 2017b). Anthropogenic factors due to fast urbanization seem to be a main contributor to impact at genomics level of aquatic organisms (Paital \& Rivera-Ingraham, 2016). Irrespective of socio-economic status of any human race, fish flesh acts as a source of consumption for easily digestible proteins and various nutraceuticals. However, scanty research on ecogenomics study of fish, high consumption, and nutraceutical value of their flesh demand more studies on fish models (Paital \& Rivera-Ingraham, 2016). This short review was aimed to gather information and to confirm on fish flesh as nutraceutical source and to check whether literature deals with their genomic instability phenomena such as single nucleotide polymorphism and epigenetic changes. These points may address to conserve the germplasm of susceptible animals especially fish under climatic changes. It may lead to better exploit the fish and fisheries' resources judiciously (Sampaio, Trindade, Varheim, Paital, Eriksson, et al., 2015).

In relation to ecogenomics studies, works on other animals than fish are not limited. However, day by day, data generated under wet laboratory experimental approaches especially the generated sequences of genes and proteins are accumulating with a high speed. It leads to a problem to handle such data especially for their annotation to reach a conclusion. This is a common issue with all animals including fish. Therefore, another focus of this short review was also to find out the issues related to handling ecogenomics data at in silico level.

\section{Main text}

\section{Literature collection on fish ecogenomics and conservation}

Articles available in PubMed site were exclusively considered for collecting literature for the present study, and relevant literature from google.com pages and other electronic databases were also included. To limit the literatures exclusively on invertebrates or fish (or any poikilothermic models) in relation to ecogenomics studies, 
"advanced" search option in PubMed was used at https://www.ncbi.nlm.nih.gov/pubmed/advanced. Under "Builder" bar, "Date-Entrez" option was selected to limit the literatures exclusively with the recent one, for example, literatures from 2010 to 2017. Each term such as "Climate change," "fresh water," "genomics," "invertebrates," and "fish" was searched alone and then combined to filter and limit the searched topic(s). This was achieved by adding each word into "history" one by one, under "builder" option. The raw data obtained was given as supplementary file, and the numbers of articles found in each hit with a single term or multiple terms were noted and plotted graphically. Nowadays, although modern tools and techniques to study ecogenomics of organisms are available, the reason(s) and possible irradiation for the cause behind scantily available literature on ecogenomics of fish were found to be less. The reason behind such scanty literature on ecogenomics of fish was also gathered from authentic electronic sources other than PubMed such as Google Scholar. To restrict the length of the article and its reference, the numbers of articles found under search option on a particular terminology such as "ecogenomics + climate change" or "ecogenomics + fish" in PubMed were only considered for counting the total number of articles. Few relevant articles out of the total result obtained, were discussed to restrict the length of references.

\section{Nutraceutical importance of fish}

Curing a disease or alleviating pain or injury by a single or combination of remedies constitutes an important part of a therapy (Hati et al., 2012; Paital et al., 2014b; Paital et al., 2017; Sahoo et al., 2017). Sometimes, diet can be used as a source for the treatment of disease(s) (Bergeron and Jacques, 1989). For example, in case of wound healing, supportive diets, especially animal proteins, are recommended in many clinical cases other than externally used antibiotics (Mat et al., 1994; Mat et al.,1998; Radinnurafiqahet al., 2016; Terkelsen et al., 2000). It is because many chemically active compounds present in various diets contribute to treat a particular symptoms of a disease or the whole disease (Kakati et al., 2006). Sometimes, such food substances are called as "having medicinal properties," are used for therapeutic purposes, and are different from pharmaceuticals (Mahawar \& Jaroli, 2008). When the formers are purified from animal or plant, they are usually called as biopharmaceuticals (Pedrono et al., 2004). More particularly, the term "nutraceuticals" is used when food or products derived from food are used as supplement for therapeutic purposes (Subudhi et al., 2009). Vitamins, minerals, highdensity fatty acids, and herbal products are few of the examples (Hege et al., 2004; Roos et al., 2002; Prabhakar \& Roy, 2009). Fisheries' products also are found to have antioxidant properties (Salte et al.,1996; Roos et al., 2002; Rooset al., 2007; Rajakumar, 2003; Prabhakar \& Roy, 2009; Paital \& Chainy, 2013a, 2013b). Therefore, Hippocrates correctly opined "Let food be thy medicine." Therefore, the cost-effective nutraceuticals have always a special demand in every section of people especially by the economically weaker section. In this context, fish and fisheries' products are used as a main resources of vital nutrients like the easily digestible proteins, high-density fats (as macronutrients), vitamins, and minerals (as micronutrients) (Zhang \& Beymen, 1993; Yao et al., 2006). Therefore, they are regarded as the "easy source of cost-effective animal proteins" and "rich food" for the people of economically weaker section, because fish protein has many beneficial physiologic role than other proteins (Sivell et al., 1984; Skeie et al., 2009).

The key nutraceuticals in flesh of fish, namely longchain polyunsaturated fatty acids (PUFA) mainly the eicosapentaenoic acid (EPA), docosahexaenoic acid (DHA), and fat-soluble vitamins, make fish diet popular (Logan, 2004; Mahata, 2002). These nutraceuticals have high role in protecting cardiovascular complications. Owing to the importance of fish and fisheries' products, a number of nutraceuticals have been used as remedies in medical sciences (Hamada \& Nagai, 1995). For example, to lessen the complications or treat diseases such as cancer, viral infections (Fernandez et al., 1999; Mozaffarian \& Rimm, 2006; Higa, 1996; Costa-Neto, 2005), rickets (Rajakumar, 2003), dermatologic problems (Ozçelik et al., 2000), hypertension especially during pregnancy (Olafsdottir et al., 2006), and parasitic (fungi and bacteria) infections (Moore et al., 1993; Agosta, 1996), fisheries' products are exclusively used as nutraceuticals. Fisheries products are also used for cardiac stimulation, as anti-tumor and analgesic (Finki, 1984; Lockington, 1878; Lesueur, 1824); for arthritis (Adeodato, 1997), as antinociceptive (Mat et al.,1997) and as anti-inflammatory (Greenhaigh \& Gamelli, 1987); for obesity (Micallef et al., 2009), to boost coagulation of blood in human (Walbaum, 1792) and other mammals (Salte et al., 1996); and for nerve cell stimulation (Colwell, 1997) and narcotic and analgesic purposes (Bisset, 1991), to handle coronary heart disease and stroke (Sidhu, 1993, 2003; Gezondheidsraad, 2004; Kris-Etherton et al., 2002); fish in diets are also believed to be used as promising nutraceuticals.

Externally used fish-derived creams also are found to be beneficial in human (Baie \& Sheikh, 2000). Important fish-derived nutraceuticals such as PUFA, EPA, DHA, protein $C$ anticoagulant, and iron (Roos et al., 2007); polybrominated diphenyl ethers and polychlorinated biphenyls (Akutsu et al., 2006); and tetrodotoxin (TTX) are resourced from fish as diet. Many important fishes such as dogfish sharks (Squalus acanthias Linnaeus 1758), Eptatretus stoutii (Lockington, 1878), Dasyatis 
sabina (Lesueur, 1824), cod, herring, salmon (especially Atlantic salmon (Salmo salar Linnaeus 1758)), sardines and turbot (Gruenwald et al., 2002; Stene et al., 2000; Adeodato, 1997), and rainbow trout (Oncorhynchus mykiss) (Walbaun, 1792; Salte et al., 1996) contribute substantially to the field of fisheries' nutraceuticals. Therefore, "ichthyotherapy" seems to be a highly emerging area of research (Grassberger \& Hoch, 2006). To proceed with the above emerging filed ecogenomics study on of fish seems to be highly important.

\section{Literature on fish ecogenomics in PubMed}

Ecogenomics is a multidisciplinary subject and considered as the union among subjects such as molecular taxonomy, ecology, and finally evolution (Glockner et al., 2016). The foremost objective of this newly emerging subject is to elucidate the mechanisms of adaptation in a new habitat. Ecological and evolutionary research frequently demonstrates that species, populations, and individuals are adapted to their own environment, i.e., the fitness of individuals is higher in their home environment than in other environments. Therefore, ecogenomics explains the adaptation of an animal in terms of longstanding genomics adaptation to grow in a new environment (Ottesen, 2016). The balance between selection and other evolutionary forces (more specifically, drift and migration) gives a clue for adaptation. The molecular mechanism to unravel the black box for environmental changes and phenotype adaptation is the primary topic in ecogenomics. It gives the mechanistic causes of phenotypic variation due to molecular adaptation including nucleotide variation in both DNA and RNA and variation in the level of gene expression. The former gives the clue for fitness variation, and incorporating genomics tools may allow identification of the genes that are actually evolving (Lee \& Mitchell-Olds, 2006). Identifying the genes affected by evolution for a better (from production point of view) and resistant (against climatic changes, habitat extremities, diseases, etc.) species selection is the key objective of ecogenomics study. It is perceived that the ecogenomics study of non-model species, reconciliation of experimental languages of ecology and evolutionary biology with molecular biology, development of specific ecogenomics data analysis tool, and adoption of a multidisciplinary cooperative research culture are the four important tasks for ecologists working on ecogenomics (Ouborg \& Vriezen, 2007). Therefore, such ecogenomics studies on fish in large scale from multi-habitats across the world could be helpful in identifying the fish variety naturally occurring with better nutraceutical values.

Literatures on climate change issues are substantially published in PubMed. Results of the literature survey on ecogenomics studies indicate that researches on climate change issues have exclusively been studied, albeit most are limited on vertebrates. The numbers of such literature, i.e., "ecogenomics in fish + climate change", were found to be very less, i.e., 392 articles out of $>27 \times 10^{3}$ total articles published on climate change issues. Articles on ecogenomics combined with bioinformatics tools on vertebrates are also very less and were $\sim 40$. And articles on ecogenomics of invertebrates, which are more susceptible to risk under climatic stressors, were almost most negligible, and results of the present study show that it is nil in PubMed (Fig. 1a, b). Similarly, various combinations searched in relation to ecogenomics in edible fish and their conservation also resulted into all total eight articles out of $>14 \times 10^{4}$ total articles on marine organisms and 58,000 articles on marine aquatic organism (Fig. 1c).

\section{Issues with ecogenomics studies and their handling}

High-speed urbanization and its consequences on climate changes that lead to conservation issues are two of the biggest challenges faced by eco-physiologists and conservationists (Paital \& Chainy, 2012a, 2012b; Paital, 2016d, 2016f; Paital \& Chainy, 2013a, 2013b). Increase in the rate of urbanization and environmental pollution have several harmful effects on human lifestyle, health and disease management matters, social and food security issues, and ultimately climate change issues (Paital, 2016c). Multiple disturbances to a larger extent in different major food chains result in considerable modulations in ecosystems. Since such processes continue in most of the developing countries such as India, where, the rate of anthroposition is high, they eventually attribute to physiology of animals from time to time. Finally, results also lead to large-scale destruction of the inhabiting organisms (Anonymous, 2017). Aquatic ecosystems are more vulnerable to be affected by such climatic extremities (Fig. 2). For example, 2 years ago and recently, large-scale die-off episodes of fishes were noticed on regular interval 5 June 2016 at the Bata River, near Balijhara (20.5136926 N, 85.6629975 E), Odisha, India. More than 500,000 fish carcasses were counted in the above area after the event had happened. Following similar episode on $8^{\text {th }}$ August, large-scale mortality of marine fishes were recorded near Gopalpur port of Odisha, India. And the contributing factors behind such disastrous fish mortality were identified as high anthroposition-induced hypoxia in Bata River and pollution in Gopalpur case. Similarly, 1,800,000 carcasses of blue buttons appeared in Astaranga beach (19 51' 37.1" $\left.\mathrm{N}+86^{\circ} 13^{\prime} 30.3^{\prime \prime} \mathrm{E}\right)$ along the east coast of Bay of Bengal, India. Similar large-scale die-off events due to climatic changes have been noticed in different places across the world (Paital \& Rivera-Ingraham, 2016). Therefore, restriction of sudden and huge changes in 


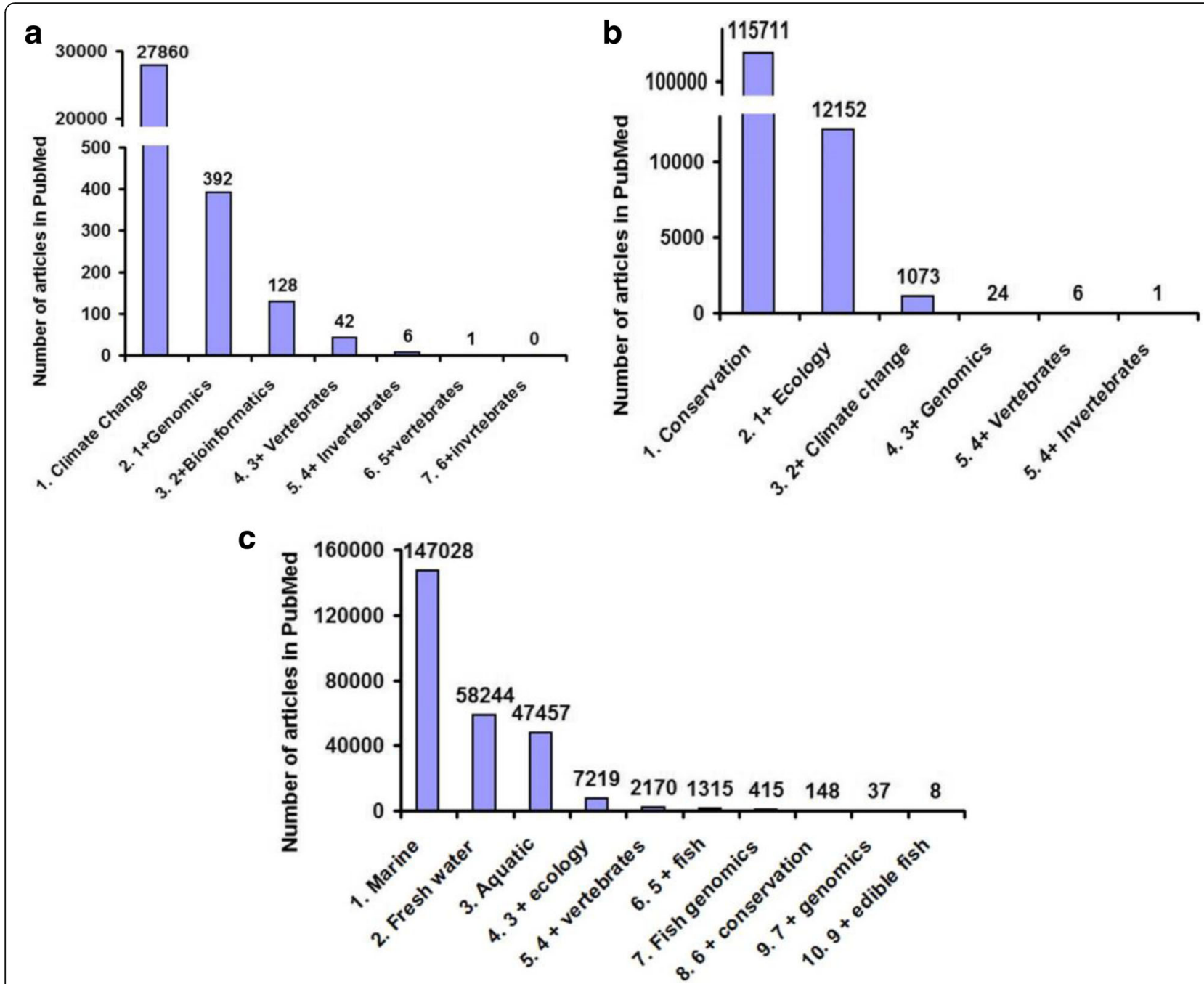

Fig. 1 Literature about ecogenomics in (edible) fish and invertebrates in relation to climate change in PubMed. a-c Figures show the search results with specific terms. Least work has been done on (edible) fish and aquatic invertebrates in relation to their ecogenomics

biodiversity due to climatic changes such as global warming and pollution are few of the challenging issues for eco-physiologists (Harvell et al., 1999; Leaf, 1989; Epstein, 1999; Tollefson, 2012). In this context, conserving the germplasm of both the susceptible and endangered (aquatic) species must be under the keen focus of researchers.

Results of the present study on literature survey in PubMed indicate that a number of published articles on climate change issues are high (Song et al., 2017) (Fig. 1). However, articles on ecogenomics changes in organisms under climatic stressor(s) are very scanty leading to less information on this important issue (Laikre et al., 2016; Petersen et al., 2016). Poikilotherms are under high risk under the changing climatic conditions. This is because of the lack of the regulatory capacity at cellular or subcellular level to climatic factors such as temperature and salinity (Paital \& Chainy, 2010, 2012b; Paital et al., 2016, b; Paital et al., 2017, 2017; Paital \& Samanta, 2013). Therefore, it is highly recommended to focus the research on climatic issues especially changes in organisms at genomics level (Shragai et al., 2017).

\section{Conservation of aquatic germplasm including fish under climatic stress conditions}

Conservation of germplasm of endangered species has now become one of the biggest challenges for biologists working on ecogenomics (Paital \& Chainy, 2012a; Luo et al., 2016). Recent case of the death of Toughie, the world's last (believed to be) Rabbs' fringe-limbed treefrog in Georgia, USA, is a latest example. It shows the symbol of the extinction crisis, when Toughie died at his home Atlanta Botanical Garden (Handwerk, 2016). The scenario is even worst in aquatic ecosystems including marine ecosystems. In mid-January 2017, it is warned that if the present rate of fossil fuel burning will not be 


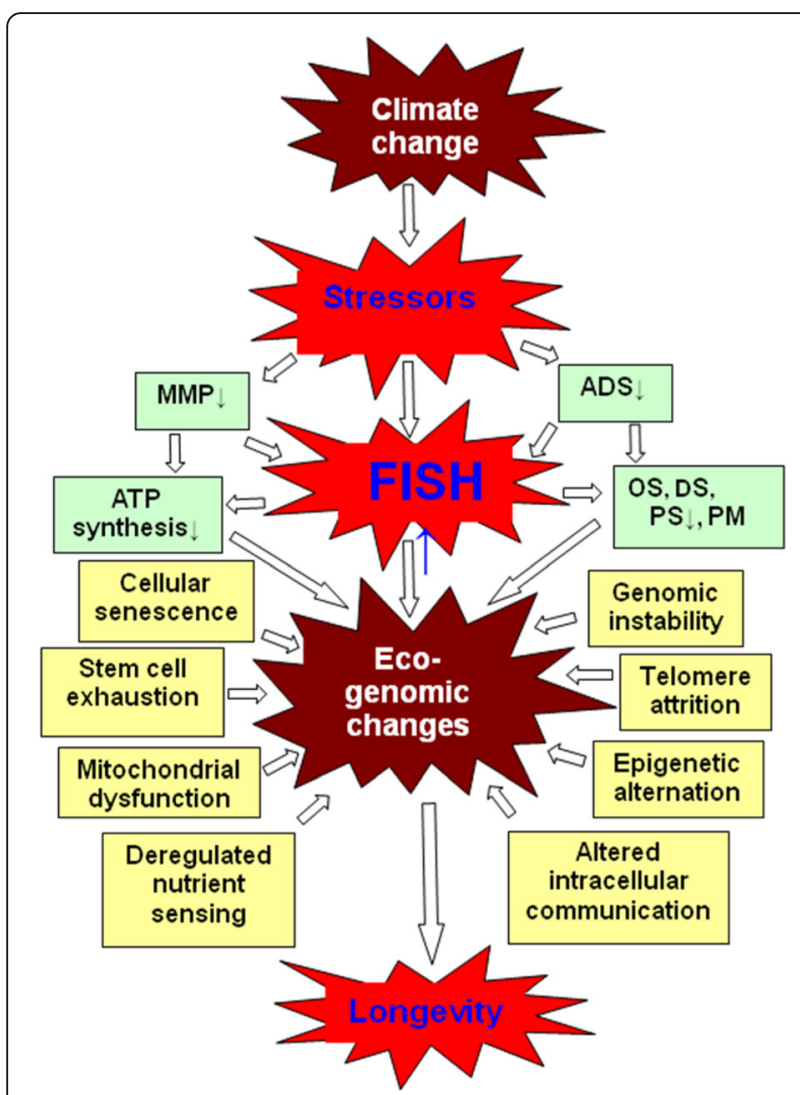

Fig. 2 Possible correlation between climate change and epigenomics in aquatic animals, for example fish, modulated by metabolism. Climate change is responsible to increase the mean global temperature which may lead to produce many unwanted metabolites such as reactive oxygen species (ROS) in susceptible aquatic animals, for example fish. Increase in single or multiple stressors such as pollutants, temperature, and salinity can also be responsible to produce ROS via diminishing antioxidant defense system (ADS) and mitochondrial membrane potential (MMP). Persistent stressors above threshold values in turn may increase epigenomics changes in animals by elevating oxidative stress. Other vital processes such as decrease in ATP synthesis, increasing the chance to disease susceptibility (DS), proteostasis (PS), and protein misfolding (PM), in animals can lead to additional ROS production, thereby disturbing heir physiology and shortening their longevity. Due to multiple and consistent aquatic stressors, physiological processes such as genomics instability, telomere shortening, and mitochondrial dysfunction can also lead to elevate genomics instability in aquatic animals which may ultimately decrease their longevity

checked and continue, it can lead to severe bleaching of coral reefs and will hit about $99 \%$ of coral reefs bleaching in each upcoming year. Coral bleaching happens due to hot environment that makes them uncomfortable. And finally, it results in rejection of the mutualism between algae zooxanthellae and corals, on which their live ultimately depends. It is calculated that about $90 \%$ of the Great Barrier Reef of Australia has been affected by the latest episodes of climate change events and $20 \%$ of corals have already been killed. As per the latest in silico analyses, models predict even more urgency to avoid upcoming alarmed conditions for corals that are vulnerable to be bleached. About 87 countries or territories home to > $500 \mathrm{~km}^{2}$ of reef. On average, these reefs are predicted to experience very high-speed annual bleaching by 2043 because of making living corals vulnerable to starvation and diseases. It ultimately can lead to a coral-free ocean, one of the alarming predictions that may lead to worsen oceanic ecosystems (Radford, 2016). This is just one of the examples of large-scale die-off events, and dramatic climatic changes are believed to be the most important contributory factors to it (Leaf, 1989).

One of the cellular mechanisms that affect population is believed to be the changes at their genomics level (Laikre et al., 2016; Petersen et al., 2016). Finally, the ecogenomics changes act as raw material for evolution. Therefore, it is suggested that standing genetic variation and new mutations, space-for-time substitutions, environmental gradients and phenotypic clines, and signatures of selection and gene expression are to be analyzed using modern wet laboratory and in silico tools (Paital, 2016a, 2016e; Paital et al., 2011, 2013, 2015b). It is to be done to quantify the magnitude and type of changes (especially genetic) in organisms as a function of climatic changes. The data obtained can be helpful for the construction of biodiversity corridors and their implications for conservation, helping in assisted migration, ex situ conservation and creation of germplasm banks, in situ conservation and protecting refugia, etc. Few such steps can be taken to conserve the genome of threatened species (NECR081, 2016). However, man-made climatic changes as a consequence of pollution can be also contributory factors for genomics and epigenetic changes that finally affect the germplasm of inhabiting organisms. Therefore, multiple approaches including ecogenomics studies, being one of the most important of them, need to be adapted to conserve the species both terrestrial and specifically aquatic that are moving slowly towards extinction (Kroeker, 2016; Barlow et al., 2016; Cinner et al., 2016). For example, the combination of the Great Barrier Reef of Australia, frequent climatic disasters such as El Nino, and permanent rise in atmospheric $\mathrm{CO}_{2}$ level to reach above threshold values (>400 ppm) and its impacts on other aquatic organisms including fish needs timely appropriate scientific approaches to be studied and handled (Paital et al., 2016, b; 2017b; Cinner et al., 2016). Otherwise, the current aquatic species susceptible to various insults may undergo rapid extinction from the ecosystem. So, urgent need of ecogenomics studies at evolutionary level is required to reveal their mechanism of extinction.

\section{Ecogenomics and evolutionary studies for conservation of organisms}

One of the major key factors for evolution is the gradual change in genome of an organism over time. The 
accumulation of such genetic changes in germ line of an organism tends to originate a new survivor on the earth-the so called new species. Undoubtedly, the process takes millions of years to manifest (Gee \& Howlett, 2009). On the other hand, pollutants along with other factors have tremendous mutagenic roles. So, the survivors and those who surpass the environmental extremities, for example, high pollution, are expected to be affected at their germ line level (Pagel, 2009) (Fig. 3). Does this process has any role in further adaptation or vulnerability of the offsprings of the survivors, should be the challenging question in eco-genetic studies. Therefore, ecogenomics studies are accepted as few of the highly demanding and emerging area of researches (Shubin et al., 2009). Not only drawing correlation between the transcript expression levels and the high environmental fluctuations, in organisms, but also the point mutation or any epigenetic changes should be correlated with climatic changes especially under pollutant exposure. Population ecology and population genetics need to be merged together to highlight the effects of climatic changes on animals (Budd \& Telford, 2009). In this regard, least works have been done on animals especially in invertebrates; those are susceptible to climatic changes (Fig. 1, Additional file 1: Figure S1).

\section{Approaches to solve ecogenomics and conservation issues}

Although literature is very less on ecogenomics studies in organisms and especially in poikilothermic models, preliminary works can be done using simple, freely available online tools. Genomics disorders as a result of climatic changes can be predicted by analyzing respective protein disorders using both in silico simulation approaches, because annotation of the genome, transcriptome, and proteome data is now becoming easier, albeit some particular challenging issues are to be dealt (Bolívar et al., 2014). For example, using bioinformatics tools such as DisEMBL, ExPASy, PONDR, GlobPlot, and NORSp, effects of temperature on protein disorder prediction, is a milestone achieved to study eco-physiology (Mizianty et al., 2011). Even metabolic signatures of an animal are studied using recent advanced techniques such as mass, Raman, and NMR spectrometries and microarray. Studying the site-specific modifications of proteins and genes such as oxidation, alkylation, phosphorylation, and methylation can give potential clues to be correlated with genetic or epigenetic changes under fluctuated environmental conditions (Misra \& van der Hooft, 2016). Among wet laboratory approaches to study the ecogenomics of organisms, next-generation sequencing is considered to be one of the most advanced technologies to reveal the genome of organisms with a short time span under any experimental condition including under eco-stressors. However, translation of the obtained data to annotate into accurate DNA sequence(s) with the above technique is a limitation and still is a challenging issue for molecular biologists

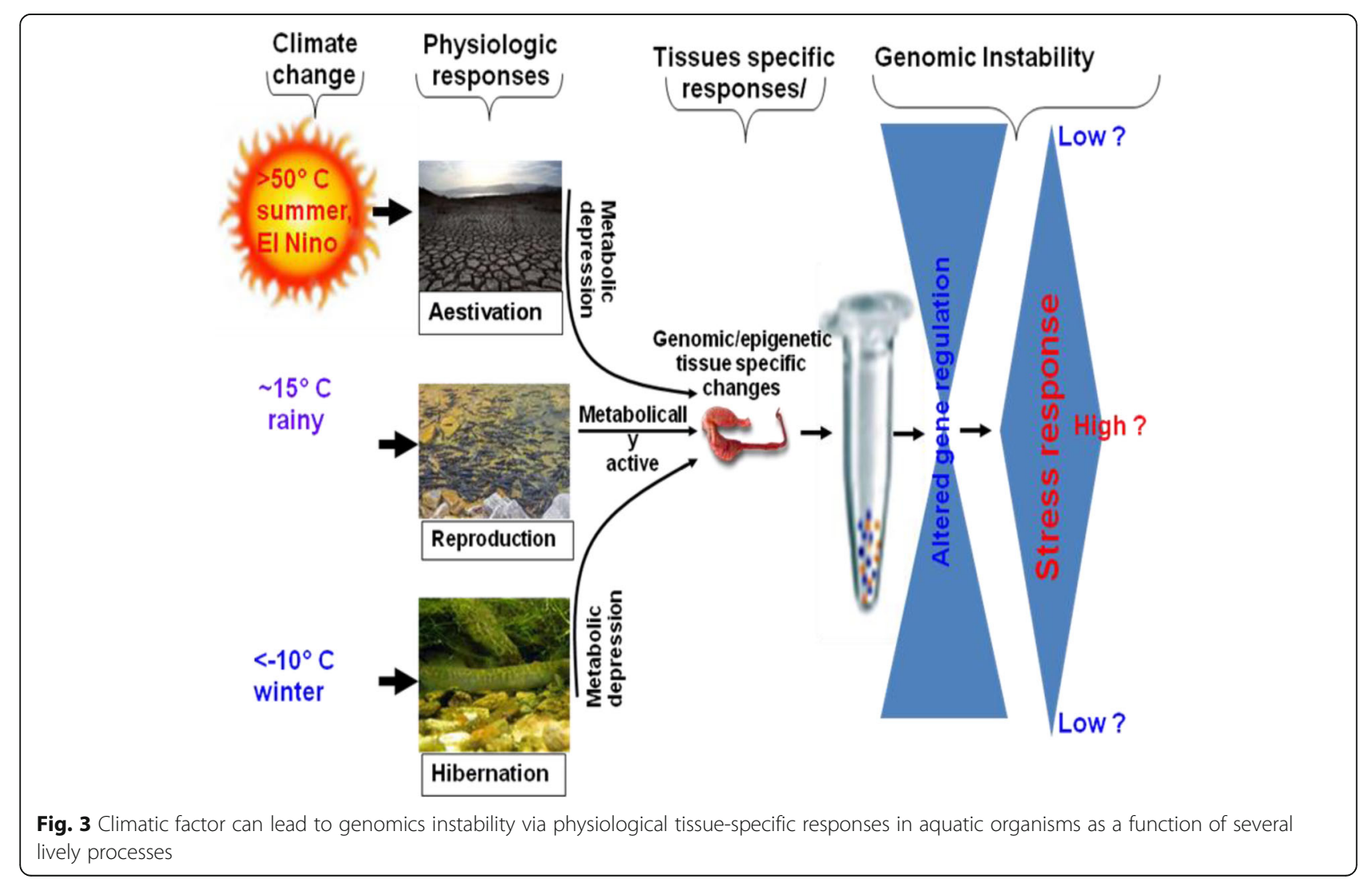


(Tongsima et al., 2011). It becomes more challenging during DNA assembly and annotation, when an unknown genome of an organism is sequenced, although by much improved computational biology and bioinformatics tools, it is gradually becoming easier (Huang et al., 2016; Paital et al., 2016, b; 2017, b, c).

To avoid such limitations, most of the current approaches should rely on the simulation of climate-change parameters under laboratory conditions to study the effects on physiology of aquatic organisms of fisheries' importance including fishes. Such simulation approaches also demand the urgency to set up and carefully monitor the changes in physiology and genomics of fishes under natural ecosystems. For example, such experimental approaches can be undertaken in parallel with satellite-based analyses of water parameters aiming to understand and predict large-scale destruction events in aquatic bodies (Paital et al., 2016, b, 2017, b). Despite some limitations, ecogenomics certainly is going to remove the issues exist in thrust areas of conservation biology and conventional conservation strategies as stated recently (Luo et al., 2016). With these newer trends in ecology and genome biology, researches have become interested to conserve the flora and fauna of the earth by several ecogenomics approaches (Luo et al., 2016; Laikre et al., 2016; Ueno et al., 2016; Falcone et al., 2016; Gernot et al., 2016) (Fig. 3). Therefore, marriage among ecology, genomics, and computational biology may clear the path of the conservationists to save the flora and fauna especially that of fishes by ecogenomics approaches. Further, it will also lead to the unraveling of several theories on the genetic basis of adaptation among fishes under changes in climatic conditions (Orr, 2015).

\section{Conclusions}

Fish flesh is a reasonably priced source of animal protein as well as considered as a cheap source of nutraceuticals such as PUFA, EPA, DHA, and TTX. However, the ratio between demand and production is increasing day by day especially in developing countries such as India. On the other hand, changing climatic conditions is also found to be a contributory factor to create challenges to reduce the above ratio. Therefore, scientific planning, management, and judicious use of fish and fisheries' resources seem to be important tasks for the present-day fishery biologist. The above tasks are found to be fortified under the changing climatic conditions. Especially, study at the genome level in various fish models as a function of climate change may give clues for the better management.

\section{Additional file}

Additional file 1: Figure S1. Literature in PubMed about ecogenomics, climate change, and conservation of animals especially aquatic animals. Each figure shows the search results with specific terms. (DOC 847 kb)

\section{Abbreviations}

DHA: Docosahexaenoic acid; DisEMBL: Website of European Molecular Biology Laboratory; EPA: Eicosapentaenoic acid; ExPASy: SIB Bioinformatics Resource Portal; GlobPlot: Predictor of intrinsic protein disorder and globularity; NORSp: Predictions of long regions without regular secondary structure.; PONDR: Predictor of Natural Disordered Regions;

PUFA: Polyunsaturated fatty acid; TTX: Tetrodotoxin

\section{Acknowledgements}

BRP acknowledges Prof. GBN Chainy, NEHU, Shillong, India, for the proof reading of the article.

\section{Funding}

BRP is highly thankful to the Science and Engineering Research Board, Department of Science and Technology, Govt. of India New Delhi, India (no. ECR/2016/001984), and Department of Science and Technology, Government of Odisha (grant letter number 1188/ST, Bhubaneswar, dated 01.03.17,

ST-(Bio)-02/2017), for providing funding.

Availability of data and materials

Not applicable

Authors' contributions

BRP has sole contribution for this article. The author read and approved the final manuscript.

\section{Authors' information}

Dr. Paital (M.Sc., M.Phil., and Ph.D. from Utkal University; PDF from BHU, India; UiTM, Malaysia; and IISc, Bangalore) is currently working as an Asst. Prof. at OUAT, India, and tries to translate research (environment upheaval induced cellular and mitochondrial stress (free radical biology)) to field level in order to exploit nutraceutical values of aquatic organisms. Ecogenomics and molecular interactions are few of his working areas. He has published 52 international and national research papers and is an acting member of the editorial board of 16 journals and reviewer board of 27 international and 9 reputed journals. Dr. Paital has received 7 awards and Life Members of 10 professional bodies. Currently, he is handling three major projects funded by Government and Private agencies.

\section{Ethics approval}

Not applicable

\section{Consent for publication}

Not applicable

\section{Competing interests}

The author declares that there are no competing interests.

\section{Publisher's Note}

Springer Nature remains neutral with regard to jurisdictional claims in published maps and institutional affiliations.

Received: 3 November 2017 Accepted: 8 February 2018

Published online: 22 February 2018

\section{References}

Adeodato, S. (1997). Os santos remedies do mar. Globo Ciencia, Abril., 4, $20-25$.

Agosta, W. (1996). Bombardier beetles and fever trees: A close-up look at chemical war fare and signals in animals and plants, (224 p). New York: AddisonWesley Publishing Company.

Akutsu, K., Tanaka, Y., \& Hayakawa, K. (2006). Occurrence of polybrominated diphenyl ethers and polychlorinated biphenyls in shark liver oil supplements. Food Additives and Contaminants, 23(12), 1323-1329.

Ali, S., Gugliemini, O., Harber, S., Harrison, A., Houle, L., Ivory, J., ... Mordecai, E. A. (2017). Environmental and social change drive the explosive emergence of Zika virus in the Americas. PLoS Neglected Tropical Diseases, 11 (2), e0005135. https://doi.org/10.1371/journal.pntd.0005135.

Anonymous. (2017). Mass animal deaths for 2017. http://www.end-times-prophecy. org/animal-deaths-birds-fish-end-times.html. Accessed 08 Dec 2017. 
Baie, S. H., \& Sheikh, K. A. (2000). The wound healing properties of Channa striatuscetrimide cream-Tensile strength measurement. Journal of Ethnopharmacology, 71, 93-100.

Barlow, J., Lennox, G. D., Ferreira, J., Berenguer, E., Lees, A. C., Mac-Nally, R., .. Gardner, T. A. (2016). Anthropogenic disturbance in tropical forests can double biodiversity loss from deforestation. Nature, 535(7610), 144-147. https://doi.org/10.1038/nature18326

Bergeron, N., \& Jacques, H. (1989). Influence of fish protein as compared to casein and soy protein on serum and liver lipids, and serum lipoprotein cholesterol levels in the rabbit. Atherosclerosis, 78, 113-121.

Bisset, N. G. (1991). One man's poison, another man's medicine? Journal of Ethnopharmacology, 32, 71-81.

Bolívar, J. C., Machens, F., Brill, Y., Romanov, A., Bülow, L., \& Heh, R. (2014). In silico expression analysis', a novel PathoPlant web tool to identify abiotic and biotic stress conditions associated with specific cis-regulatory sequences. Database: The Journal of Biological Databases and Curation, 10, 030. https://doi.org/10.1093/database/bau030.

Buczkowski, G., \& Bertelsmeier, C. (2017). Invasive termites in a changing climate: A global perspective. Ecology and Evolution, 7(3), 974-985. https://doi.org/10. 1002/ece3.2674 eCollection 2017.

Budd, G. E., \& Telford, M. J. (2009). The origin and evolution of arthropods. Nature 457, 812-817. https://doi.org/10.1038/nature07890.

Carey, F. G., \& Lawson, K. D. (1973). Temperature regulation in free-swimming blue fin tuna. Comp. Biochem. Physiol. Part A., 44(2), 375-392.

Chainy, G. B. N., Paital, B., \& Dandpat, J. (2016). An overview of seasonal changes in oxidative stress and antioxidant defence parameters in some invertebrate and vertebrate species Scientifica. Article number 6126570. 1-8 pages. https://doi.org/10.1155/2016/6126570.

Cinner, J. E., Huchery, C., MacNeil, M. A., Graham NA, McClanahan TR, Maina J, .... \& Mouillot D. (2016). Bright spots among the world's coral reefs. Nature 535(7612), 416-419. https://doi.org/10.1038/nature18607.

Colwell, R. R. (1997). Microbial biodiversity and biotechnology. In M. L. ReakaKudla et al. (Eds.), Biodivcrsity II: Understanding and protecting our biological resources, (pp. 77-78). Washington, D.C.: Joseph Henry Press.

Costa-Neto EM. (2005). Animal-based medicines: Biological prospection and the sustainable use of zootherapeutic resources. An. Acad. Bras. Ciênc. 77(1), 3343. https://doi.org/10.1590/S0001-37652005000100004.

Epstein, P. R. (1999). Climate and health. Science, 285(5426), 347-348.

Eriksson, H., Österblom, H., Crona, B., Troell, M., Andrew, N., Wilen, J. \& Folke, C. (2015). Contagious exploitation of marine resources. Frontiers in Ecology and the Environment, 13: 435-440. https://doi.org/10.1890/140312.

Falcone, E., Grandoni, L., Garibaldi, F., Manni, I., Filligoi, G., Piaggio, G., \& Gurtner, A. (2016). Infinity: An in-silico tool for genome-wide prediction of specific DNA matrices in miRNA genomic loci. PLoS One, 11(4), e0153658. https://doi.org/10.1371/journal.pone.0153658.

Fernandez, E., Chatenoud, L., La Vecchia, C., Negri, E., \& Franceschi, S. (1999). Fish consumption and cancer risk. The American Journal of Clinical Nutrition, 70, 85-90.

Finki, C. W. (1984). Os medicamentos do mar. In J. Y. Cousteau (Ed.), Enciclopédia dos Mares, v. 1, (pp. 74-75). Rio de Janeiro: Salvat.

Galli, G. L. J., \& Richards, J. G. (2012). The effect of temperature on mitochondrial respiration in permeabilized cardiac fibres from the freshwater turtle, Trachemys scripta. Journal of Thermal Biology, 37(3), 195-200. https://doi.org/ 10.1016/j.jtherbio.2011.12.012.

Gee, H., \& Howlett, R. (2009). Evolution. Nature, 457(7231), 807-848. https://doi.org/10.1038/457807a.

Gezondheidsraad. Terminale sedatie. Publicatienummer (2004). In: Signalering Ethiek en Gezondheid. (2004). ISBN 90-5549-527-1.

Glöckner, G., Lawal, H. M., Felder, M., Singh, R., Singer, G., Weijer, C. J., \& Schaap, P. (2016). The multicellularity genes of dictyostelid social amoebas. Nature Communications, 7(12085), 1-11. https://doi.org/10.1038/ncomms12085.

Goldman, K. J. (1997). Regulation of body temperature in the white shark, Carcharodon carcharias. J. Comp. Physiol. Part B, 167(6), 423-429. https://doi.org/10.1007/s003600050092.

Grassberger, M., \& Hoch, W. (2006). Ichthyotherapy as alternative treatment for patients with psoriasis: A pilot study. eCAM, 3(4), 483-488.

Greenhaigh, D. G., \& Gamelli, R. L. (1987). Is impaired wound healing caused by infection or nutritional depletion? Surgery, 102, 306-312.

Gruenwald, J., Graubaum, H. J., \& Harde, A. (2002). Effect of cod liver oil on symptoms of rheumatoid arthritis. Advances in Therapy, 19, 101-107.

Hamada, M., \& Nagai, T. (1995). Inorganic components of bones of fish and their advanced utilization. J. Shimonoseki Univ. Fish., 43, 185-194.
Handwerk, B. (2016). Famous frog Toughie dies, sending species to extinction. http://news.nationalgeographic.com/2016/09/toughie-rabbs-fringe-limbedtree-frog-dies-goes-extinct/. Retrieved on 12.09.2016.

Harvell, C. D., Kim, K., Burkholder, J. M., Colwell, R. R., Epstein, P. R., Grimes, D. J., ... Vasta, G. R. (1999). Emerging marine diseases — climate links and anthropogenic factors. Science, 285(5433), 1505-1510.

Hati, A. K., Paital, B., Naik, K. N., Mishra, A. K., Chainy, G. B. N., \& Nanda, L. K. (2012). Constitutional, organopathic and combined homeopathic treatment of benign prostatic hypertrophy: A clinical trial. Homeopathy, 101, 217-223. https://doi.org/10.1016/j.homp.2012.08.005.

Hege, W., Bjrn, L., Gudbrandsen, O. A., Lied, E., Espe, M., Muna, Z., ... Berge, R. K. (2004). Fish protein hydrolysate reduces plasma total cholesterol increases the proportion of HDL cholesterol, and lowers acyl-COA: Cholesterol acyltransferase activity in liver of Zucker rats. The Journal of Nutrition, 134, 1320-1327.

Hermoso, V. (2017). Freshwater ecosystems could become the biggest losers of the Paris agreement. Global Change Biology, 23(9), 3433-3436. https://doi.org/ 10.1111/gcb.13655

Higa, T. (1996). Introduction. J. Toxicology-Toxin Reviews, 15, vii.

Huang, C. L., Hsu, T. W., Chou, C. H., Chiang, Y. C, \& Chiang T. Y. (2016). Miscanthus as an example of ecological genetics and genomics for nonmodel species. Ecol. Gen. Genom. 1(2016), 6-7. https://doi.org/10.1016/j.egg.2015.10.003.

Kakati, L. N., Bendang, A., \& Doulo, V. (2006). Indigenous knowledge of zootherapeutic use of vertebrate origin by the a tribe of Nagaland. Journal of Human Ecology, 19(3), 163-167.

Kris-Etherton, P. M., Harris, W. S., \& Appel L. J. (2002). American Heart Association. Nutrition Committee. Fish consumption, fish oil, omega-3 fatty acids, and cardiovascular disease. Circulation 106(21), 2747-2757.

Kroeker, K. J. (2016). Conservation: Fishing for lessons on coral reefs. Nature, 535(7612), 361-362. https://doi.org/10.1038/535361a.

Laikre, L., Olsson, F., Jansson, E., Hössjer, O., \& Ryman, N. (2016). Metapopulation effective size and conservation genetic goals for the Fennoscandian wolf (Canis lupus) population. Heredity 117(2016), 279-289. https://doi.org/10. 1038/hdy.2016.44.

Leaf, A. (1989). Potential health effects of global climate and environmental changes. The New England Journal of Medicine 321(23), 1577-1583. https:// doi.org/10.1056/NEJM198912073212305.

Lee, C. E., \& Mitchell-Olds, T. (2006). Preface to the special issue: Ecological and evolutionary genomics of populations in nature. Molecular Ecology, 15, 1193-1196.

Lefevre, S., McKenzie, D. J., \& Nilsson, G. E. (2017). Models projecting the fate of fish populations under climate change need to be based on valid physiological mechanisms. Global Change Biology, 23(9), 3449-3459. https://doi.org/10.1111/gcb.13652.

Lesueur, C. A. (1824). Description of several new species of Holothuria. Journal Academy Natural Sciences of Philadelphia., 4, 155-163.

Lockington, (1878). In: Froese, R. and D. Pauly. Editors. (2017). FishBase. Accessed through: World Register of Marine Species at http://marinespecies.org/aphia. php/aphia.php? $\mathrm{p}=$ taxdetails\&id=316613 retrieved on 2017-09-18

Logan, A. C. (2004). Omega-3 fatty acids and major depression: A primer for the mental health professional. Lipids in Health and Disease, 3(1), 25.

Luo, Z., Tang, S., Jiang, Z., Chen, J., Fang, H., \& Li, C. (2016). Conservation of terrestrial vertebrates in a global hotspot of karst area in southwestern China. Scientific Reports 6, 1-12. https://doi.org/10.1038/srep25717.

Mahata, M. C. (2002). Edible shell fish (Molluscs) of Chotanagpur Plateau, Tharkhand (India), (pp. 1-133). Baripada, Orissa: Bio-publications.

Mahawar, M. M., \& Jaroli, D. P. (2008). Traditional zootherapeutic studies in India: A review. Journal of Ethnobiology and Ethnomedicine. 4, 17..

Markovic, D., Carrizo, S. F., Kärcher, O., Walz, A., \& David, J. N. (2017). Vulnerability of European freshwater catchments to climate change. Global Change Biology 23 (9), 3567-3580. https://doi.org/10.1111/gcb.13657.

Mat Jais, A. M., Dambisya, Y. M., \& Lee, T. L. (1997). Antinociceptive activity of Channa striatus (Haruan) extracts in mice. Journal of Ethnopharmacology, 57, 125-130.

Mat Jais, A. M., Matori, M. F., Kittakoop, P., \& Suwanborirux, K. (1998). Fatty acid composition in mucus and roe of Haruan, Channa Striatus, for wound healing. General Pharmacology, 30(56), 1-563.

Mat Jais, A. M., McCullock, R., \& Croft, K. (1994). Fatty acid and amino acid composition in Haruan as a potential role in wound healing. General Pharmacology, 25, 947-950.

Micallef, M., Munro, I., Phang, M., \& Garg, M. (2009). Plasma n-3 fatty acids are negatively associated with obesity. The British Journal of Nutrition, 102(9), 1370-1374.

Millán, J., Cevidanes, A., Chirife, A. D., Candela M. G., \& León-Vizcaíno L. (2017). Risk factors of Leptospira infection in Mediterranean periurban 
micromammals. Zoonoses Publication Health. 65 (1), e79-e85. https://doi. org/10.1111/zph.12411

Misra, B. B., \& van der Hooft J. J. J. (2016). Updates in metabolomics tools and resources: 2014-2015. Electrophoresis 37(1), 86-110. https://doi.org/10.1002/ elps.201500417.

Mizianty, M. J., Zhang, T., Xue, B., Zhou, Y., Dunker, A. K., Uversky, V. N., \& Kurgan, L. (2011). In-silico prediction of disorder content using hybrid sequence representation. BMC Bioinformatics 12(245), 1-16. https://doi.org/10.1186/ 1471-2105-12-245

Moore, K. S., Wehrli, S., Roder, H., Rogers, M., Forrest Jr., J. N., MeCrimmon, D., et al. (1993). Squalamine: An aminosterol antibiotic from the shark. Proceedings of the National Academy of Sciences of the United States of America, 90(4), 1354-1358.

Mozaffarian, D., \& Rimm, E. B. (2006). Fish intake, contaminants, and human health evaluating the risks and the benefits. JAMA, 296(15), 1885-1899.

NECR081. (2016). Natural England Commissioned Report NECR081. Adapting conservation to a changing climate. https://www.academia.edu/ 27987640/Common_conservation_challenges_in_a_changing_climate. Retrieved on 12.09.2016.

Olafsdottir, A. S., Skuladottir, G. V., Thorsdottir, I., Hauksson, A., Thorgeirsdottir, H. \& Steingrimsdottir, L. (2006). Relationship between high consumption of marine fatty acids in early pregnancy and hypertensive disorders in pregnancy. BJOG, 113, 301-309.

Orr, H. A. (2015). The genetic theory of adaptation: A brief history. Nat. Rev Gen. 6(2205), 119-127. https://doi.org/10.1038/nrg1523.

Ottesen, E. A. (2016). Probing the living ocean with ecogenomic sensors. Current Opinion in Microbiology, 31, 132-139. https://doi.org/10.1016/j.mib.2016.03.012

Ouborg, N. J., \& Vriezen, W. H. (2007). An ecologist's guide to ecogenomics. Journal of Ecology, 95, 8-16.

Ozçelik, S., Polat, H. H., Akyol, M., Yalçin, A. N., Ozçelik, D., \& Marufihah, M. (2000). Kangal hot spring with fish and psoriasis treatment. The Journal of Dermatology, 27(6), 386-390.

Pagel, M. (2009). Overview article natural selection 150 years on. Nature 457, 808811. https://doi.org/10.1038/nature07889.

Paital, B. (2013). Antioxidant and oxidative stress parameters in brain of Heteropneustes fossilis under air exposure condition; role of mitochondrial electron transport chain. Ecotoxicology and Environmental Safety, 95, 69-77. https://doi.org/10.1016/j.ecoenv.2013.05.016.

Paital, B. (2014a). A modified fluorimetric method for determination of hydrogen peroxide using homovanillic acid oxidation principle BioMed Research International. 2014, Article ID 342958, 1-8 pages., https://doi.org/10.1155/2014/342958.

Paital, B. (2014b). Modulation of redox regulatory molecules and electron transport chain activity in muscle of air breathing fish Heteropneustes fossilis under air exposure stress. Journal of Comparative Physiology. B 184, 65-76. https://doi.org/10.1007/s00360-013-0778-8

Paital, B. (2016a). Mass spectrophotometry: An advanced technique in biomedical sciences. Advanced Techniques in Biology and Medicine, 4(182), 1-8. https:// doi.org/10.4172/2379-1764.1000182.

Paital, B. (2016b). Oxidative stress and ageing in animals under thermal stress due to global warming: A perspective. Research Journal of Biological Sciences, 4(1), 4-8.

Paital, B. (2016c). RE: Full speed ahead to the city on the hill. Science, 352(6288), 1-2. http://science.sciencemag.org/content/352/6288/886/tab-e-letters.

Paital, B. (2016d). Role of cyclonic storm as natural disaster and other factors on vulture mortality in India. Journal of Geography and Natural Disasters, 6(165), 1-5. https://doi.org/10.4172/2167-0587.1000165.

Paital, B. (2016e). Sector based mass spectrometry: An advanced technique in metabolomics and proteomics. Research Journal of Biological Sciences, 4(2), 55-57.

Paital, B. (2017). Redox regulation in animals to slow down ageing. Journal of Bioresearch Communications, 1(1), 1-2.

Paital, B., Bal, A., Rivera-Ingraham, G. A., \& Lignot, J. H. (2017). Increasing frequency of large-scale die-off events in the bay of Bengal: Reasoning, perceptive and future approaches. Indian Journal of Geo-Marine Sciences Accepted.

Paital, B., \& Bohidar, K. (2011). Effect of dietary alpha glycine on cocoon production in the silk worm Bombyx mori. Current Trends in Biotechnology and Pharmacy, 5, 1157-1162.

Paital, B., \& Chainy, G. B. N. (2010). Antioxidant defenses and oxidative stress parameters in tissues of mud crab (Scylla serrata) with reference to changing salinity. Comparative Biochemistry and Physiology. C, 151, 142-151. https://doi. org/10.1016/j.cbpc.2009.09.007

Paital, B., \& Chainy, G. B. N. (2012a). Biology and conservation of the genus Scylla in India subcontinent. Journal of Environmental Biology, 33, 871-879.
Paital, B., \& Chainy, G. B. N. (2012b). Effects of salinity on $\mathrm{O}_{2}$ consumption, ROS generation and oxidative stress status of gill mitochondria of the mud crab Scylla serrata. Comparative Biochemistry and Physiology. C, 155, 228-237. https://doi.org/10.1016/j.cbpc.2011.08.009.

Paital, B., \& Chainy, G. B. N. (2013a). Modulation of expression of SOD isoenzymes in mud crab (Scylla serrata): Effects of inhibitors, salinity and season. Journal of Enzyme Inhibition and Medicinal Chemistry, 28, 195-204. https://doi.org/10. 3109/14756366.2011.645239.

Paital, B., \& Chainy, G. B. N. (2013b). Seasonal variability of antioxidant biomarkers in mud crabs (Scylla serrata). Ecotoxicology and Environmental Safety, 87, 3341. https://doi.org/10.1016/j.ecoenv.2012.10.006.

Paital, B., \& Chainy, G. B. N. (2014). Effects of temperature on complex I and II mediated mitochondrial respiration, ROS generation and oxidative stress status in gills of the mud crab Scylla serrata. Journal of Thermal Biology, 41, 104-111. https://doi.org/10.1016/j.jtherbio.2014.02.013.

Paital, B., \& Chainy, G. B. N. (2016). Redox metabolism in fishes under thermal stress warrants more attention. Journal of Fisheriessciences.com, 10(1), 22-26.

Paital, B., Das, S., \& Dutta, S. K. (2015). Biochemical and environmental insights of declining vulture population in some Asian countries. Current Trends in Biotechnology and Pharmacy, 9(4), 389-410.

Paital, B. Das, S., \& Dutta, S. K. (2016). Diclofenac induced vulture deaths in Odisha, India: Time to debate or conserve them? Pharmaceutica Analytica Acta, 7(9), 1-2. https://doi.org/10.4172/2153-2435.1000508.

Paital, B., Hati, A. K., Naik, K. N., Mishra, A. K., Nanda, L. K., \& Chainy, G. B. N. (2014). Re: Editorial comment on constitutional, organopathic and combined homeopathic treatment of begin prostatic hypertrophy: A clinical trial: S. A. Kaplan. Journal of Urology, 190, 1818-1819 J. Urol., 193, 1-2. https://doi.org/10 1016/j.juro.2014.04.088.

Paital, B., Hati, A. K., Nayak, C., Mishra, A. K., \& Nanda, L. K. (2017). Combined effects of constitutional and organopathic homeopathic medicines for better improvement of benign prostatic hyperplasia cases. International Journal of Clinical \& Medical Images, 4(7), 1-2. https://doi.org/10.4172/2376-0249.1000574.

Paital, B., Jahan, T., Priyadarshini, S., \& Mohanty, A. (2017). Antioxidants and ageing. Open Journal of Environmental Biology, 2(1), 021-022.

Paital, B., Kumar, S., Farmer, R., Tripathy, N. K., \& Chainy, G. B. N. (2011). In silico prediction and characterization of $3 \mathrm{D}$ structure and binding properties of catalase from the commercially important crab, Scylla serrata. Interdisciplinary Sciences: Computational Life Sciences, 3, 110-120. https://doi.org/10.1007/ s12539-011-0071-z

Paital, B., Kumar, S., Farmer, R., Tripathy, N. K., \& Chainy, G. B. N. (2013). In silico prediction of 3D structure of superoxide dismutase of Scylla serrata and its binding properties with inhibitors. Interdisciplinary Sciences: Computational Life Sciences, 5, 69-76. https://doi.org/10.1007/s12539-013-0150-4.

Paital, B., Panda, S. K., Hati, A. K., Mohanty, B., Mohapatra, M. K., Kanungo S., Chainy, G. B. N. (2016). Longevity of animals under reactive oxygen species stress and disease susceptibility due to global warming. World Journal of Biological Chemistry. 7(1), 110-127. https://doi.org/10.4331/wjbc.v7.i1.110.

Paital, B., \& Rivera-Ingraham, G. A. (2016). High speed urbanization and its effects on aquatic food chain especially on fish in Bata river of Odisha, India. Journal of Fisheriessciences.com, 10(4), 1-3.

Paital, B., Sablok, G., Kumar, S., Singh, S. K., \& Chainy, G. B. N. (2015). Investigating the conformational structure and potential site interactions of SOD inhibitors on Ec-SOD in marine mud crab Scylla serrata: A molecular modeling approach. Interdisciplinary Sciences: Computational Life Sciences, 8, 312-318. https://doi.org/10.1007/s12539-015-0110-2.

Paital, B., \& Samanta, L. (2013). A comparative study of hepatic mitochondrial oxygen consumption in four vertebrates by using Clark-type electrode. Acta Biologica Hungarica, 64, 152-160. https://doi.org/10.1556/ABiol.64.2013.2.2.

Paital, B., \& Tripathy, S. (2015). Possible reasons of vulture mortality and their remedial measures with special reference to Indian context. Everyman's Science. XLIX (6), 356-362.

Paital, B. R., Tripathy, S., Dutta, S. K., \& Samantaray, R. K. (2014). Vulture mortality: An analysis in Indian context. e-planet, 11(2), 48-59.

Paital, B. R. E. (2016f). 2016 science news at glance. Science, 352(6290), 1-2. http://science.sciencemag.org/content/352/6290/1148/tab-e-letters.

Pedrono, F., Martin, B., Leduc, C., Le Lan, J., Saiag, B., Legrand, P., et al. (2004). Natural alkylglycerols restrain growth and metastasis of grafted tumors in mice. Nutrition and Cancer, 48(1), 64-69.

Petersen, S. V., Dutton, A., \& Lohmann, K. C. (2016). End-cretaceous extinction in Antarctica linked to both Deccan volcanism and meteorite impact via climate change. Nature Communications 7, 1-9. https://doi.org/10.1038/ncomms12079. 
Prabhakar, A. K., \& Roy, S. P. (2009). Ethno-medicinal uses of some shell fishes by people of Kosi River basin of North-Bihar, India. Ethno-Med, 3(1), 1-4.

Radford, T. (2016). World's reefs caught up in the longest global coral bleaching event ever recorded. http://www.ecowatch.com/coral-reef-bleaching2194496268.html. Accessed 09 Dec 2016.

Radinnurafiqah, M., Paital, B., Kumar, S., Abubaker, S., \& Tripathy, S. (2016). $\mathrm{AgNO}_{3}$ dependant modulation of glucose mediated respiration kinetics in Escherichia Coli at different pH and temperature. Journal of Molecular Recognition, 29(11), 544-554. https://doi.org/10.1002/jmr.2554.

Rajakumar, K. (2003). Vitamin D, cod-liver oil, sunlight, and rickets: A historical perspective. Pediatrics, 112(2), 32-135.

Rocha, S., Kerdelhué, C., Ben Jamaa, M. L., Dhahri, S., Burban, C., \& Branco, M. (2017). Effect of heat waves on embryo mortality in the pine processionary moth. Bulletin of Entomological Research, 10, 1-9. https://doi.org/10.1017/ S0007485317000104.

Roos, N., Leth, T., Jakobsen, J., \& Thilsted, S. H. (2002). High vitamin A content in some small indigenous fish species in Bangladesh: Perspectives for foodbased strategies to reduce vitamin a deficiency. Mt. International Journal of Food Sciences and Nutrition, 53, 425-537.

Roos, N., Thorseng, H., Chamnan, C., Larsen, L., Gondolf, U. H., \& Thilsted, S. H. (2007). Iron content in common Cambodian fish species: Perspectives for intake in poor, rural households. Food Chemistry, 104(3), 1226-1235.

Sahoo, A. R., Paital, B., Taneja, D., \& Hati, A. K. (2017). Knowledge, attitude and practice of Anganwadi workers on homoeopathic formulations. Indo American Journal of Pharmaceutical Research, 7(10), 574-581.

Salte, R., Norberg, K., \& Odegaard, O. R. (1996). Evidence of a protein c-like anticoagulant system in bony fishes. Thrombosis Research, 83, 389-397.

Samanta, L., \& Paital, B. (2016). Effects of seasonal variation on oxidative stress physiology in natural population of toad Bufo melanostictus; clues for analysis of environmental pollution. Environ. Sc. Poll. Res., 23(22), 22819-22831. https://doi.org/10.1007/s11356-016-7481-8.

Shragai, T., Tesla, B., Murdock, C., \& Harrington, L. C. (2017). Zika and chikungunya: Mosquito-borne viruses in a changing world. Annals of the New York Academy of Sciences, 1399(1), 61-77. https://doi.org/10.1111/nyas.13306.

Shubin, N., Tabin, C., \& Carroll, S. (2009). Deep homology and the origins of evolutionary novelty. Nature 457, 818-823. https://doi.org/10.1038/ nature07891.

Sidhu, G.S. (1993). Lipids in food and their role in human health: Assessment of some nutritional and technological aspects of fats and cholesterol modified foods. Division of Food Science and Technology, CISRO, North Ryde, Aus tralia .pp. 1-139.

Sidhu, K. S. (2003). Health benefits and potential risks related to consumption of fish or fish oil. Regulatory Toxicology and Pharmacology, 38, 336-344.

Sivell, L. M., Bull, N. L., Buss, D. H., Wiggins, R. A., Scuffam, D., \& Jackson, P. A. (1984). Vitamin A activity in foods of animal origin. Journal of the Science of Food and Agriculture, 35, 931-939.

Skeie, O., Braaten, T., Hjarta, A., Brustad, M., \& Lund, E. (2009). Cod liver oil, other dietary supplements and survival among cancer patients with solid tumors. International Journal of Cancer, 125, 1155-1160.

Song, X., Wang, S., Hu, Y., Yue, M., Zhang, T., Liu, Y., ... Shang, K. (2017). Impact of ambient temperature on morbidity and mortality: An overview of reviews. Science of the Total Environment, 586, 241-254. https://doi.org/10.1016/j. scitotenv.2017.01.212.

Stene, L. C., Ulriksen, J., Magnus, P., et al. (2000). Use of cod liver oil during pregnancy associated with lower risk of type I diabetes in the offspring. Diabetologia, 43, 1093-1098. https://doi.org/10.1007/s001250051499.

Subudhi, U., Das, K., Paital, B., Bhanja, S., \& Chainy, G. B. N. (2008). Alleviation of enhanced oxidative stress and oxygen consumption of L-thyroxin induced hyperthyroid rat liver mitochondria by vitamin E and curcumin. ChemicoBiological Interactions, 173, 105-114. https://doi.org/10.1016/j.cbi.2008.02.005.

Subudhi, U., Das, K., Paital, B., Bhanja, S., \& Chainy, G. B. N. (2009). Supplementation of curcumin and vitamin E enhances oxidative stress, but restores hepatic histoarchitecture in hypothyroid rats. Life Sciences, 84, 372379. https://doi.org/10.1016/j.lfs.2008.12.024

Terkelsen, L. H., Eskild-Jensen, A., Kjeldsen, H., Barker, J. H., \& Hjortdal, V. E. (2000) Topical application of cod liver oil ointment accelerates wound healing: An experimental study in wounds in the ears of hairless mice. Journal of Plastic, Reconstructive \& Aesthetic Surgery, 34(1), 15-20.

Tollefson, J. (2012). Heat waves blamed on global warming FREE. Nature, 488, 143-144. https://doi.org/10.1038/488143a.
Tongsima, S., Assawamakin, A., Piriyapongsa, J., \& Shaw, P. J. (2011). Comparative view of in silico DNA sequencing analysis tools. Methods in Molecular Biology, 760, 207-221. https://doi.org/10.1007/978-1-61779-176-5_13.

Ueno, K., Ibarra, M., \& Gojobori, T. (2016). Structural adaption of extremophile proteins to the environments with special reference to hydrophobic networks. Ecol. Gen. Genom. 1, 1-5. https://doi.org/10.1016/j.egg.2015.10.001.

Walbaum, 1792. In: Froese, R. and D. Pauly. Editors. (2017). FishBase. Accessed through: World Register of Marine Species at http://www.marinespecies.org/ aphia.php?p=taxdetails\&id=305984 on 2017-09-18.

Wu, J., Miao, C., Zhang, X., Yang, T., \& Duan, Q. (2017). Detecting the quantitative hydrological response to changes in climate and human activities. Sci. Total Environ., 586, 328-337. https://doi.org/10.1016/j.scitotenv.2017.02.010.

Yao, H. T., Chang, Y. W., Lan, S. J., Chen, C. T., Hsu, T., \& Yeh, T. K. (2006). The inhibitory effect of polyunsaturated fatty acids on human CYP enzymes. Life Sciences, 79(26), 2432-2440.

Zhang, X., \& Beymen, A. C. (1993). Influence of dietary fish proteins on plasma and liver cholesterol concentrations in rats. The British Journal of Nutrition, 69, 767-777. 